\title{
14. Stakeholder engagement in sustainability transitions $^{1}$
}

\author{
Lara Gonzalez-Porras, Anna Heikkinen, Johanna Kujala \\ and Riikka Tapaninaho
}

\section{THE STAKEHOLDER APPROACH TO SUSTAINABILITY TRANSITIONS}

It has been claimed that systemic change encompassing various levels and multiple actors in society is needed to solve the current sustainability crisis (Glasbergen, 2010). To achieve this, business organizations with their stakeholders, among other societal actors, need to be involved to enhance sustainable development in the society (Dentoni et al., 2017). Sustainable development can be defined as the "development that meets the needs of the present without compromising the ability of future generations to meet their own needs" (World Commission on Environment and Development, 1987, p. 8). Previous research has demonstrated that the current business practices have contributed to creating sustainability challenges, such as climate change, poverty and resource deficiencies (Pattberg \& Widerberg, 2016); nevertheless, firms also control crucial capabilities and resources needed to solve sustainability problems (Loorbach et al., 2010; Rhodes et al., 2014). However, research on how firms can engage with their stakeholders to contribute to societal change in the direction of sustainability is scarce.

Using stakeholder theory (Freeman, 1984) as a starting point, in this chapter we examine the key assumptions and characteristics of stakeholder engagement in sustainability transitions and how such engagement may further these transitions. For this purpose, we focus on firmstakeholder relationships and build on relational stakeholder theory (Freeman et al., 2010; Kujala \& Sachs, 2019; Kujala et al., 2019). Stakeholders are defined as individuals or groups that can affect or be affected by the achievement of a firm's objectives (Freeman, 1984).

In this chapter, stakeholder engagement refers to diverse stakeholder relationships and multiple stakeholder interactions. Stakeholder engagement, which embodies the ideas of stakeholder theory, can be defined as organizational practices aimed at involving stakeholders in a positive and collaborative manner in the activities of a firm (Greenwood, 2007). It involves stakeholder identification, relationship-building among stakeholders, the alignment of stakeholder interests, internal and external communication, stakeholder dialogue and learning with and from stakeholders (Kujala \& Sachs, 2019; O'Riordan \& Fairbrass, 2014; Smith, 2017). It has been acknowledged as a useful practice for jointly addressing challenging issues and creating value (Aakhus \& Bzdak, 2015; Freeman et al., 2017).

By sustainability transitions, we refer to "long-term, multi-dimensional and fundamental transformations of large socio-technical systems towards more sustainable modes of production and consumption" (Markard et al., 2012, p. 956). Transformations of socio-technical systems entail changes in technological, material, organizational, institutional, political, economic and socio-cultural dimensions (Markard et al., 2012). Thus, sustainability transitions require collaboration across various sectors if new ways of doing, thinking and organizing are 
to be established in order to move towards a more sustainable society (Avelino \& Wittmayer, 2016; Frantzeskaki \& Rok, 2018; McKee et al., 2014). Previous research on sustainability transitions has adopted various theoretical perspectives, including transition management, strategic niche management, the multi-level perspective and that of technological innovation systems (Fischer \& Newig, 2016; Kivimaa et al., 2019; Markard et al., 2012).

Here we employ the stakeholder engagement perspective, maintaining that sustainability transitions involve cross-sector and multi-level collaboration between various actors, including firms, government, society and science (Foxon et al., 2004; Glasbergen, 2010; Köhler et al., 2019; Peer \& Stoeglehner, 2013; Webb et al., 2018). Firms urgently need to move towards adopting sustainable production and consumption systems, a goal requiring engagement and collaboration with their stakeholders. For instance, integrative engagement with consumers and employees can result in the development and improvement of a firm's capabilities to create sustainability innovations (Watson et al., 2018). The role of the government is also decisive, as it establishes the policies and regulations to support sustainability transformations (Foxon et al., 2004; Hörisch et al., 2014). As for the role of science: educators, researchers and disseminators of sustainability practices can all trigger sustainability transitions (Hörisch et al., 2014; Webb et al., 2018).

We understand change agency as the potential to promote and bring about change (Pelenc et al., 2015). Previous research has suggested that both individual stakeholders and stakeholder groups can act as change agents that accelerate transitions towards sustainability (Dentoni et al., 2017; Goodman et al., 2017; Pesch, 2015). Stakeholder engagement is often perceived as a tool that leads to dialogic change processes and accelerates systemic change in favour of sustainability (Pruitt et al., 2005). However, only a few studies have addressed stakeholder engagement from the viewpoints of sustainability transitions or change agency, even though it is widely known that sustainability transitions require stakeholder engagement and collaboration (Köhler et al., 2019; Mont et al., 2014).

The rest of this chapter proceeds as follows: In the next section, we describe our data collection and analysis, after which we review and discuss previous research on stakeholder engagement in sustainability transitions. Our findings examine stakeholder engagement on four levels: those of the individual, the firm, industry and society. This multi-level analysis highlights the assumptions and characteristics related to stakeholder engagement across a broad field. Based on our findings, we suggest that, in addition to approaching stakeholders as change agents, stakeholder engagement as a relational process can be understood as change agency in sustainability transitions. The chapter concludes with a discussion of the contributions made by our study and future research suggestions.

\section{THE COLLECTION AND ANALYSIS OF STUDIES ON STAKEHOLDER ENGAGEMENT}

To examine stakeholder engagement in sustainability transitions, we conducted a literature review of peer-reviewed, scholarly articles published from 2000 to 2020 using the following electronic databases: Emerald Insight, JSTOR Business Collection I and ScienceDirect (Elsevier). We used the following search terms, to be found within all fields of the full-text articles: "stakeholder", "multi-stakeholder", "stakeholder engagement", "stakeholder collaboration" and "stakeholder agency", in combination with "systemic change", "systemic transfor- 
mation", "sustainability transition" and "transition management". Our search resulted in 101 articles. The articles were read to assess their relevance to our literature review, a screening that yielded 37 articles (see Table 14A.1 in the Appendix).

The analysis initially focused on identifying the different levels of stakeholder engagement, finding four commonly utilized in the literature: (1) the individual level; (2) the firm level; (3) the industry level; and (4) the societal level (Avelino \& Wittmayer, 2016; Dentoni et al., 2017; Fischer \& Newig, 2016; Köhler et al., 2019; Loorbach et al., 2010). While these levels are interrelated, an examination of each, individually, provides significant results. Next, the articles were systematically analysed to identify the assumptions and characteristics of stakeholder engagement at each level in the context of sustainability transitions. Figure 14.1 describes the four levels of our analysis.

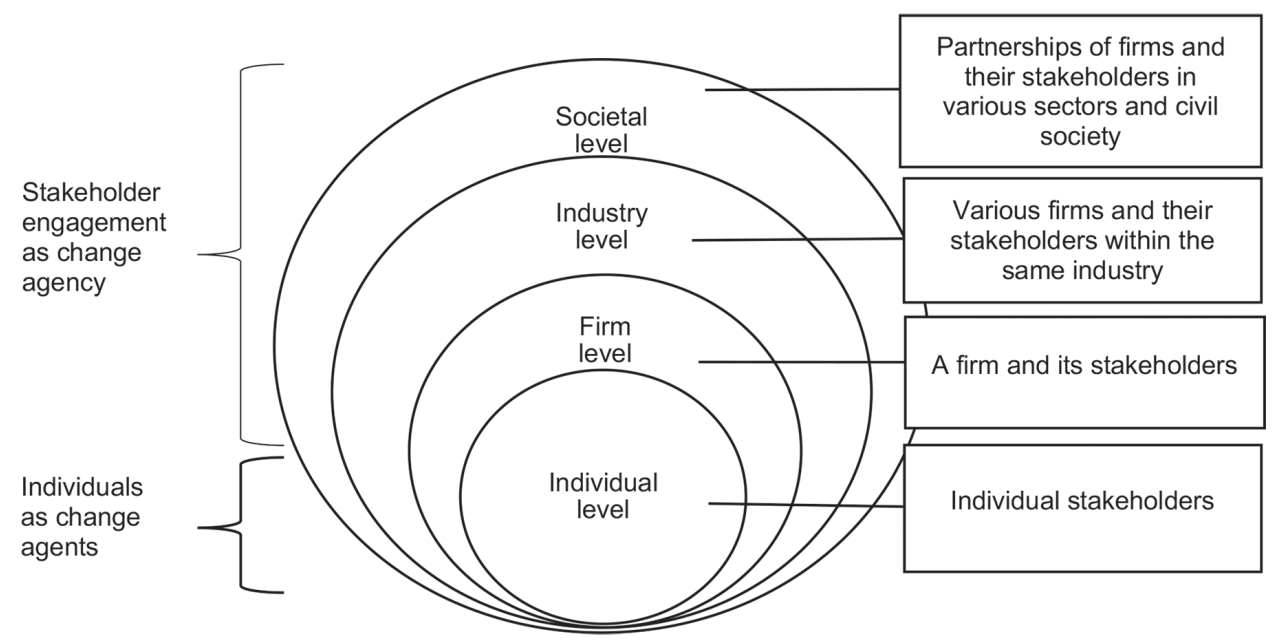

Figure 14.1 Levels of stakeholder engagement in sustainability transitions

To examine stakeholder engagement at each level, we systematically analysed the articles in terms of stakeholder relationships and interactions. The individual level of stakeholder engagement focuses on stakeholders as change agents (Pelenc et al., 2015). While this level examines actors and their actions rather than stakeholder relationships and interactions, it is frequently addressed in the literature and therefore warrants discussion (Fischer \& Newig, 2016; Goodman et al., 2017; Koistinen et al., 2020). At the firm level, stakeholder engagement refers to relationships and interactions between a firm and its internal and external stakeholders, such as its employees, suppliers or customers (Bulgacov et al., 2015; Loorbach et al., 2010; Pelenc et al., 2015; Sulkowski et al., 2018). The industry level involves various firms that, together with their stakeholders, interact with other companies and their stakeholder sets within the same industry, creating networks in order to address common concerns (McKee et al., 2014; Millar et al., 2012; Mutoko et al., 2014). Finally, at the societal level, we discuss cross-sector partnerships in which various firms and their stakeholders from different sectors interact with civil society to bring about systemic change and promote sustainability transitions (Glasbergen, 2010; Köhler et al., 2019; Pattberg \& Widerberg, 2016; Waddell, 2016). 
Within this level, we include stakeholders such as non-governmental organizations (NGOs), local communities, governments, cities and the media.

\section{LEVELS OF STAKEHOLDER ENGAGEMENT}

\section{Individual Level}

The sustainability transitions literature has mostly taken a system-level perspective; however, attention has also been paid to individual stakeholders and their agency - in other words, their potential to act and bring about change (Fischer \& Newig, 2016). These individual stakeholders can shape sustainability in their own contexts and, as members of society, initiate significant societal change (Avelino, 2009).

The individual level focuses on stakeholders acting as change agents and on the actions and practices that support and initiate sustainability transitions. Stakeholders fitting this category identified in the literature include niche actors (supporting radical socio-technical ideas), regime actors (existing inside or outside an incumbent regime) and landscape actors present in the background; actors within the societal realm; intermediaries; opposing and supporting actors; and individual stakeholders that operate at local, regional and national levels of governance (Fischer \& Newig, 2016). Moreover, individual stakeholders, such as policymakers, consumers and managers, can assume different roles in sustainability transitions, such as frontrunner, champion and intermediary (Avelino \& Wittmayer, 2016). Frontrunners are those individual stakeholders who have the competence and capacity to create, and then operate within, newly emerging divergent structures in regimes (Brown et al., 2013), while champions, such as policy entrepreneurs, have the power to lead sustainability change by developing new niches (Brown et al., 2013). Intermediaries are individual stakeholders who build bridges between actors and across different scales and levels (Brown et al., 2013), supporting transitions towards sustainable development by, for example, representing the natural environment, increasing the visibility of environmental issues or connecting non-human nature with other stakeholders (Hörisch et al., 2014).

Research at the individual level has also explicated the motivations of individual stakeholders for contributing to sustainability transitions; education, for instance, has been identified as one of these (Mont et al., 2014). A life course perspective has identified four further factors explaining sustainability-based agency development and the maintenance of individual stakeholders over time: the actor's life path, the actor's mindset, the interplay between the actor's personal motivations and collective expectations, and the actor's holistic lifestyle as it relates to sustainability (Koistinen et al., 2020).

Understanding individual stakeholders' choices, attitudes and motivations (Köhler et al., 2019) is focal for examining the micro-level view of sustainability transitions and bottom-up processes, as changes in individual practices and mindsets (Pesch, 2015) may lead to societal transformations when supported by the institutional environment (Mutoko et al., 2014). Furthermore, research has recognized that individual stakeholders can contribute to creating sustainability-oriented innovations: new products, services or practices whose implementation leads to transformations and improvements in social and ecological systems (Goodman et al., 2017; Westley et al., 2011). Individual stakeholders can also have a proactive role in innovation processes, acting as stimulators, initiators, brokers/mediators, concept refiners, 
legitimators, educators, context enablers and impact extenders (Goodman et al., 2017). They can support the generation and implementation of socio-technical innovations like low-energy housing during the emerging phase of these technologies (Köhler et al., 2019). Furthermore, they can adapt their everyday practices to facilitate these innovations during the acceleration phase of these technologies by, for instance, making sustainable consumption choices (Köhler et al., 2019).

The notion of discursive fields, referring to "bodies of meanings with which actors engage in social action" (Pesch, 2015, p. 379), has been used to explain individual stakeholders' change processes at the niche level, starting with the establishment of the niche and ending with the scaling up of the niche and its effects to higher societal levels (Pesch, 2015). Some discursive fields are more prone to enhancing sustainability change and generating action than others, depending on their degree of discursive fixation (Pesch, 2015). In discursive fields with a high degree of fixation, current rules and beliefs are strongly embedded and therefore hinder actions and changes initiated by individual stakeholders. In discursive fields with a low degree of fixation, on the other hand, the discursive field is open and individual stakeholders can easily enunciate, change and share their visions, expectations and values. When engaging in sustainability transitions, individual stakeholders can occasionally present conflicting views and values. Nevertheless, they can reframe contradictory approaches and reach agreements that accelerate sustainability transitions through strategies such as co-creating, supporting, making and forcing change, all of which require the establishment of common goals and interests among individual stakeholders (Dentoni et al., 2017).

\section{Firm Level}

This level refers to stakeholder engagement occurring within a firm as well as between a firm and its stakeholders. The focus is on the firm's direct stakeholders, referring to those who are vital for its operations and/or for implementing corporate sustainability practices that trigger sustainability transitions (Bulgacov et al., 2015).

Previous research has examined both internal and external firm-level stakeholders. Managers have received particular attention as internal stakeholders due to their influence on the process of integrating sustainability into corporate activities. Managers' sustainability worldviews, together with the firm context in which the company in question is embedded, influence how companies approach sustainability; and these worldviews also impact on how firms relate to their stakeholders in addressing sustainability issues through, for instance, the involvement of employees and stakeholder communication (van den Berg et al., 2019). Stakeholder engagement at the firm level also depends on the context in which the company operates. The presence of a supportive environment, especially one exhibiting sustainability-based policy, political leadership and support, is also highly significant (Mont et al., 2014; Rhodes et al., 2014; Waddell, 2016). Meanwhile, external stakeholders, such as the government, are highlighted for their key role in establishing regulations and promoting infrastructures that support firms in the context of sustainability transitions (Foxon et al., 2004; Mont et al., 2014); researchers are also considered to play an important role as disseminators of sustainability practices (Hörisch et al., 2014).

At the firm level, stakeholder engagement in promoting sustainability depends on the firm's internal characteristics, such as the company's human capital, the organizational culture, the leadership style, the technology available and the nature of the collaborative processes with 
stakeholders (Rhodes et al., 2014). Stakeholder engagement in terms of moving towards sustainability involves stakeholder collaboration, communication and dialogue (Sulkowski et al., 2018). By proactively interacting with stakeholders, a company can alter its stakeholders' behaviour, create networks, co-innovate and improve its core operations to initiate changes in society and the market simultaneously (Sulkowski et al., 2018).

Stakeholder engagement can help create organizational capabilities enabling firms, together with their stakeholders, to promote sustainability-based innovations (Loorbach et al., 2010). It has been determined that specific organizational capabilities are needed to develop sustainability-oriented innovations: for instance, operational capabilities, such as environmental reporting, marketing skills for product development and technological expertise (Watson et al., 2018). Additionally, first-order dynamic capabilities, including external and internal integrative capabilities, are required to manage firms' engagement with internal and external stakeholders through agreements on common goals, knowledge and data sharing (Watson et al., 2018). Second-order dynamic capabilities, such as value framing and systematized learning capabilities, are needed both to learn from stakeholder engagement activities and coalitions, and to reframe conflicting stakeholder views (Watson et al., 2018). Research has noted, however, that stakeholders' contradictory values and views may provide an opportunity for collaboration and environmental innovation (Loorbach et al., 2010; Watson et al., 2018).

To conclude, stakeholder engagement at the firm level can act as change agency in sustainability transitions by establishing firm-stakeholder relationships that support sustainability. Such engagement depends on the business and political contexts in which the firm operates, while business-led systemic societal changes are often steered by the motivations of firm managers. Thus, firm-level stakeholder engagement can lead to business practices and sustainability-related organizational capabilities that trigger sustainability innovations.

\section{Industry Level}

At this level, stakeholder engagement occurs between various firms and their stakeholders interacting and engaging within the same industry. While the current literature on sustainability transitions has scarcely explored the potential of business coalitions within industries, a few studies have acknowledged the importance of industry-level collaboration (Markard et al., 2012; Penzenstadler et al., 2013). For instance, Millar et al. (2012) recognize the need for collaborative relationships between key actors in the business supply chain to solve environmental challenges, as well as the relevance of establishing networks through, for instance, meta-industry alliances, industry-specific associations, issue-based networks, supplier-buyer partnerships and company-NGO partnerships.

The goal of industry-level networks is to co-create knowledge, value and solutions regarding environmental problems and sustainability challenges (Millar et al., 2012). Business and industry networks also shape societal discourses, frames and expectations concerning sustainability issues (Köhler et al., 2019). Additionally, they promote the development of policies, regulations, industry standards and industry legitimacy, and contribute to the development of technological innovations that transform markets and support the emergence of new industries (Köhler et al., 2019).

The establishment of these networks requires, first, the identification of possible collaborative partners and the creation of cooperative relationships with other firms; second, the development of norms and procedures that support inter-organizational learning and knowledge 
sharing; and, third, a change in the basic assumptions operating within the firm, which in turn will bring about more significant changes outside the network (Millar et al., 2012).

More concretely, Mutoko et al. (2014) provide an empirical example of industry-level collaboration by exploring it in the context of land management at rural and local levels, with the objective of identifying elements that enhance large-scale transformations. The authors conclude that land management practices can be improved through technological innovations that trigger technical transitions when augmented by a supportive policy environment and stakeholder collaboration at multiple scales (Mutoko et al., 2014). This type of stakeholder collaboration requires resource sharing, mobilization in stakeholder networks and partnerships, and the alignment of stakeholders' objectives and activities towards a shared goal and demand for change (Mutoko et al., 2014).

Collaborative processes in inter-firm networks are driven by aims that include gaining knowledge and expertise, accessing resources and improving each participant's legitimacy through an inter-organizational learning process based on diverse dyadic relationships and interactions between the actors (Millar et al., 2012). This is a process that requires a dialogical approach and a high level of trust (Millar et al., 2012).

We conclude that industry-level stakeholder engagement related to sustainability transitions is based on collaborative relationships and networks between key actors in the business supply chain. Industry networks can shape societal discourses, frames and expectations concerning sustainability issues, helping to enhance and accelerate the transformation of the market. Moreover, examining industry-level networks leads to the exploration of inter-organizational learning processes as well as the co-creation of knowledge, value and solutions to environmental problems and sustainability challenges.

\section{Societal Level}

The societal level has been widely discussed in the literature. It refers to cross-sector partnerships that incorporate various firms and diverse stakeholders from multiple sectors and industries who, together with civil society actors - NGOs, local communities, governments, cities and the media - seek to solve sustainability challenges and enable sustainability transitions. Solving sustainability challenges is a joint effort between various actors requiring the active involvement, commitment and empowerment of all relevant stakeholders (Kolk, 2014; Mont et al., 2014; Van de Kerkhof, 2006). Previous research has especially highlighted the key roles of local communities, civil society organizations and social movements, defined as networks composed of individuals, firms and actors from different sectors whose objective is to change established assumptions, institutions and systems in order to enhance systemic change (Köhler et al., 2019; Smith \& Iversen, 2018).

Stakeholder engagement at the societal level involves multi-stakeholder partnerships, defined as collaborative spaces that involve business and civil society organizations aiming to find common solutions to complex societal challenges, thereby triggering systemic change (Dentoni et al., 2018). It can also operate at the global action level, involving multi-stakeholder, cross-sectoral, inter-organizational networks that focus on sustainability issues and aim to create systemic change globally (Glasbergen, 2010). These networks may subsume stakeholders such as governments, firms and civil society in order to develop debates, research, joint initiatives and collective action geared towards sustainability (Glasbergen, 2010). Intermediary stakeholders play a key role at the societal level, as they build bridges and estab- 
lish relationships between actors and across different scales and levels (Brown et al., 2013; Kivimaa et al., 2019).

Stakeholder engagement takes place in partnerships in which various business organizations and stakeholders from different sectors interact and collaborate. These partnerships are characterized by more fluid hierarchical structures and the existence of cross-sector collaboration (Pruitt et al., 2005; Senge et al., 2007); thus, it is a form of association that requires the development of shared views and cooperative relationships based on trust, dialogue and joint learning in order to create common actions and initiatives for systemic change (Rhodes et al., 2014; Senge et al., 2007).

At the societal level, stakeholder engagement is characterized as comprising a range of dialogical collaborative practices leading to knowledge sharing and learning. Multi-stakeholder dialogue plays a key role in promoting societal change through partnerships, as the inherent cross-sectoral collaboration within these partnerships is enhanced through human interactions, communication, conversations, negotiations and agreements (Pruitt et al., 2005). Stakeholder dialogue may be improved by processes of learning and argumentation in which stakeholders interact to promote environmental change (Van de Kerkhof, 2006). Furthermore, through dialogical interactions, stakeholders can learn how to turn conflicting views and interests into shared views, agreement, consensus and joint solutions that enhance sustainability transitions (Van de Kerkhof, 2006).

Another important aspect of stakeholder engagement at the societal level is the specific learning process that occurs within multi-stakeholder partnerships. Stakeholder engagement can lead to transformative social learning in which various actors set joint goals and actions at different levels that lead to knowledge sharing and solve common concerns (McKee et al., 2014). Transformative social learning includes the process of reframing, in which actors engage in dialogue to agree on shared perceptions of problems, joint actions and creative, innovative solutions (McKee et al., 2014). Previous research has also explored the concept of multi-stakeholder engagement spaces in which multiple actors "exchange ideas, dialogue on issues and solutions and interactions concerning targeted problems and their proposed solutions" (Frantzeskaki \& Rok, 2018, p. 48).

Stakeholder engagement at the societal level can lead to the development of innovations and value co-creation for sustainability transitions. According to Mont et al. (2014), establishing interactions among different stakeholders can bring about change and social innovations that meet societal needs. This change can be related to societal behaviour that supports sustainability, such as sustainable consumption and production, or the creation of sustainable urban initiatives (Mont et al., 2014). Stakeholder engagement can also lead to value creation by reinforcing stakeholders' interests, combining resources and capabilities, and sharing views and common goals (Watson et al., 2018). Thus, resource-based, synergistic and interaction-related value can be created from the stakeholder relationships that emerge during the engagement process (Watson et al., 2020). Analysing business-non-profit engagement in innovation development, Watson et al. (2020) concluded that, despite the actors' conflicting values, non-profit organizations can contribute to creating the external knowledge required to develop sustainability-oriented innovations.

The literature has noted a number of factors relevant to partnership success. First, stakeholder engagement requires policies, regulations, market-based instruments, voluntary agreements and state support that provide a stable framework for supporting sustainability transitions (Foxon et al., 2004). Second, fruitful stakeholder engagement requires empower- 
ment, equity, trust and learning. More concretely, stakeholder engagement should start and continue throughout all decision-making processes, representing all the relevant stakeholders, setting clear objectives and highlighting the need for appropriate skills and the knowledge to grasp complex dynamic socio-ecological systems and evaluate technical solutions to environmental challenges (Reed, 2008). Moreover, the performance of multi-stakeholder partnerships depends on conditions such as effective leadership, an optimal partner mix without power asymmetries, concrete norms and shared goals, sufficient funding, effective management and communication strategies that support learning, active meta-governance and a favourable socio-political context (Pattberg \& Widerberg, 2016).

Finally, multi-stakeholder partnerships can lead to different types of sustainability transitions. According to Pruitt et al. (2005), first-order change is based on rules and does not affect stakeholder relationships, second-order change focuses on improving system limitations through stakeholder interactions, and third-order change leads to fundamental, radical transformations by modifying the system structure through various collaborative stakeholder relationships. The ultimate goal of multi-stakeholder initiatives is to bring about third-order change, that is, sustainability transitions (Pruitt et al., 2005).

To conclude, stakeholder engagement at the societal level can act as change agency in sustainability transitions when it is understood as a relational and collaborative process that requires multi-sector relationships. To understand systemic change, different stakeholders have been highlighted - emphasizing the importance of intermediaries - and multi-stakeholder, cross-sectoral, inter-organizational partnerships have been analysed. Moreover, this level has focused on knowledge sharing, learning and dialogue in stakeholder partnerships, as well as the development of innovations and value co-creation leading to sustainability transitions. Finally, success factors and different types of transitions have been discussed to cast light on stakeholder engagement in sustainability transitions.

\section{STAKEHOLDER ENGAGEMENT AS CHANGE AGENCY}

This chapter makes three significant contributions to connecting stakeholder engagement and sustainability transitions research. First, we have identified four levels at which stakeholder engagement in sustainability transitions can be analysed: the level of the individual, the firm, the industry and society. The individual level presents individual stakeholders as change agents, while at the firm, industry and societal levels, stakeholder engagement is understood as involving various stakeholder relationships and interactions that can act as change agency to trigger sustainability transitions. While individual stakeholders have their own agencies and capabilities, their collaboration gives rise to collective agency and collective capabilities that, in turn, generate groups and other structures at the firm, industry and societal levels that enhance sustainability transitions (Pelenc et al., 2015). Thus, this collaboration bridges the gap between individual stakeholders and groups at the firm, industry and societal levels.

Second, this chapter emphasizes how stakeholder engagement enhances sustainability transitions. It can be understood as a relational, multi-level process that requires continuous stakeholder collaboration based on communication, resource sharing and shared interests (Kolk, 2014; Loorbach et al., 2010; Pelenc et al., 2015). We particularly argue that stakeholders' collaborative relationships and interactions are the key component in stakeholder engagement that accelerates sustainability transitions. 
Third, our examination has shown that stakeholder engagement can be understood as change agency in sustainability transitions. The literature has discussed stakeholders as change agents that accelerate transitions towards sustainability (Dentoni et al., 2017; Goodman et al., 2017; Pesch, 2015) and has also acknowledged that sustainability transitions require stakeholder engagement and collaboration (Köhler et al., 2019; Mont et al., 2014). Our chapter connects these perspectives and contributes to the discussion by presenting the idea of stakeholder engagement as a relational process that can be understood as change agency in sustainability transitions.

Our conceptual examination provides ample avenues for future research. First, additional conceptual perspectives could be used to enhance the theoretical understanding of stakeholder engagement in sustainability transitions, such as an issue-based stakeholder approach. Second, multi-level empirical examinations of stakeholder engagement through case studies would validate the notion of stakeholder engagement as change agency. Third, as current research mainly focuses on stakeholder engagement in sustainability transitions at the individual and societal levels, additional studies at the firm and industry levels are needed. Further research on how stakeholder engagement develops across the different levels, connecting them all, is also encouraged. Finally, deeper analysis of the dynamics of collaboration and competition that emerge during the stakeholder engagement process in sustainability transitions at the different levels is highly recommended; this could involve empirical research on resource sharing practices, learning processes and methods for resolving stakeholders' conflicting interests.

\section{CONCLUSIONS}

This chapter has examined how stakeholder engagement can support sustainability transitions in society. For this purpose, we executed a literature review of 37 articles discussing stakeholder engagement in sustainability transitions. We used a multi-level approach to organize our findings and discussed the assumptions and characteristics of stakeholder engagement on four nested levels: the individual, firm, industry and societal levels. We conclude that, in addition to approaching stakeholders as change agents, stakeholder engagement as a relational and collaborative process can be understood as change agency enhancing sustainability transitions.

\section{ACKNOWLEDGEMENTS}

The authors gratefully acknowledge the financial support from the Academy of Finland (Decision number 298663) and the Strategic Research Council at the Academy of Finland (Decision numbers 320194 and 320206).

\section{NOTE}

1. This is an open access work distributed under the Creative Commons Attribution-NoDerivatives 4.0 International (CC BY-ND 4.0). Users can redistribute the work for non-commercial purposes, as long as it is passed along unchanged and in whole, as detailed in the License. Edward Elgar Publishing Ltd must be clearly credited as the rights holder for publication of the original work. Any 
translation or adaptation of the original content requires the written authorization of Edward Elgar Publishing Ltd.

\section{REFERENCES}

The 37 articles used in our literature review are marked with asterisk $\left(^{*}\right)$ in the reference list.

Aakhus, M. and M. Bzdak (2015), 'Stakeholder engagement as communication design practice', Journal of Public Affairs, 15 (2), 188-200.

*Avelino, F. (2009), 'Empowerment and the challenge of applying transition management to ongoing projects', Policy Sciences, 42 (4), 369-390.

*Avelino, F. and J. M. Wittmayer (2016), 'Shifting power relations in sustainability transitions: A multi-actor perspective', Journal of Environmental Policy \& Planning, 18 (5), 628-649.

*Brown, R. R., M. A. Farrelly and D. A. Loorbach (2013), 'Actors working the institutions in sustainability transitions: The case of Melbourne's stormwater management', Global Environmental Change, 23 (4), 701-718.

*Bulgacov, S., M. P. Ometto and M. R. May (2015), 'Differences in sustainability practices and stakeholder involvement', Social Responsibility Journal, 11 (1), 149-160.

*Dentoni, D., V. Bitzer and G. Schouten (2018), 'Harnessing wicked problems in multi-stakeholder partnerships', Journal of Business Ethics, 150 (2), 333-356.

*Dentoni, D., S. Waddell and S. Waddock (2017), 'Pathways of transformation in global food and agricultural systems: Implications from a large systems change theory perspective', Current Opinion in Environmental Sustainability, 29, 8-13.

*Fischer, L. B. and J. Newig (2016), 'Importance of actors and agency in sustainability transitions: A systematic exploration of the literature', Sustainability, 8 (5), 476-496.

*Foxon, T., Z. Makuch, M. Mata and P. J. Pearson (2004), 'Towards a sustainable innovation policy institutional structures, stakeholder participation and mixes of policy', paper presented at the Human Dimensions of Global Environmental Change Conference, Berlin, 3-4 December.

*Frantzeskaki, N. and A. Rok (2018), 'Co-producing urban sustainability transitions knowledge with community, policy and science', Environmental Innovation and Societal Transitions, 29, 47-51.

Freeman, R. E. (ed.) (1984), Strategic Management: A Stakeholder Approach, Marshfield, MA: Pitman.

Freeman, R. E., J. S. Harrison, A. C. Wicks, B. L. Parmar and S. De Colle (eds) (2010), Stakeholder Theory: The State of the Art, Cambridge: Cambridge University Press.

Freeman, R. E., J. Kujala and S. Sachs (eds) (2017), Stakeholder Engagement: Clinical Research Cases, Cham, Switzerland: Springer Verlag.

*Glasbergen, P. (2010), 'Global action networks: Agents for collective action', Global Environmental Change, 20 (1), 130-141.

*Goodman, J., A. Korsunova and M. Halme (2017), 'Our collaborative future: Activities and roles of stakeholders in sustainability-oriented innovation', Business Strategy and the Environment, 26 (6), 731-753.

Greenwood, M. (2007), 'Stakeholder engagement: Beyond the myth of corporate responsibility', Journal of Business Ethics, 74 (4), 315-327.

*Hörisch, J., R. E. Freeman and S. Schaltegger (2014), 'Applying stakeholder theory in sustainability management: Links, similarities, dissimilarities, and a conceptual framework', Organization \& Environment, 27 (4), 328-346.

*Kivimaa, P., W. Boon, S. Hyysalo and L. Klerkx (2019), 'Towards a typology of intermediaries in sustainability transitions: A systematic review and a research agenda', Research Policy, 48 (4), 1062-1075.

*Köhler, J., F. W. Geels, F. Kern, J. Markard, E. Onsongo, A. Wieczorek, ... and L. Fünfschilling (2019), 'An agenda for sustainability transitions research: State of the art and future directions', Environmental Innovation and Societal Transitions, 31, 1-32.

*Koistinen, K., S. Teerikangas, M. Mikkilä and L. Linnanen (2020), 'Active sustainability actors: A life course approach', Sustainable Development, 28 (1), 208-223. 
*Kolk, A. (2014), 'Partnerships as a panacea for addressing global problems: On rationale, context, impact and limitations', in M. M. Seitanidi and A. Crane (eds), Social Partnerships for Responsible Business: A Research Handbook, London: Routledge, pp. 15-43.

Kujala, J., H. Lehtimäki and R. E. Freeman (2019), 'A stakeholder approach to value creation and leadership', in A. Kangas, J. Kujala, A. Heikkinen, A. Lönnqvist, H. Laihonen and J. Bethwaite (eds), Leading Change in a Complex World: Transdisciplinary Perspectives, Tampere: Tampere University Press, pp. 123-143.

Kujala, J. and S. Sachs (2019), 'The practice of stakeholder engagement', in J. S. Harrison, J. B. Barney, R. E. Freeman and R. A. Phillips (eds), The Cambridge Handbook of Stakeholder Theory, Cambridge: Cambridge University Press, pp. 227-241.

*Loorbach, D., J. C. van Bakel, G. Whiteman and J. Rotmans (2010), 'Business strategies for transitions towards sustainable systems', Business Strategy and the Environment, 19 (2), 133-146.

* Markard, J., R. Raven and B. Truffer (2012), 'Sustainability transitions: An emerging field of research and its prospects', Research Policy, 41 (6), 955-967.

*McKee, A., K. Holstead, L. A. Sutherland, T. Pinto-Correia and H. Guimarães (2014), 'Shift happens: Co-constructing transition pathways towards the regional sustainability of agriculture in Europe', paper presented at 11th European IFSA Symposium, Farming Systems Facing Global Challenges: Capacities and Strategies, Berlin, 1-4 April.

*Millar, C., P. Hind, A. Ryan, I. K. Mitchell and S. Daskou (2012), 'An interaction and networks approach to developing sustainable organizations', Journal of Organizational Change Management, 25 (4), 578-594.

*Mont, O., A. Neuvonen and S. Lähteenoja (2014), 'Sustainable lifestyles 2050: Stakeholder visions, emerging practices and future research', Journal of Cleaner Production, 63, 24-32.

*Mutoko, M. C., C. A. Shisanya and L. Hein (2014), 'Fostering technological transition to sustainable land management through stakeholder collaboration in the western highlands of Kenya', Land Use Policy, 41, 110-120.

O'Riordan, L. and J. Fairbrass (2014), 'Managing CSR stakeholder engagement: A new conceptual framework', Journal of Business Ethics, 125 (1), 121-145.

*Pattberg, P. and O. Widerberg (2016), 'Transnational multistakeholder partnerships for sustainable development: Conditions for success', Ambio, 45 (1), 42-51.

Peer, V. and G. Stoeglehner (2013), 'Universities as change agents for sustainability - framing the role of knowledge transfer and generation in regional development processes', Journal of Cleaner Production, 44, 85-95.

Pelenc, J., D. Bazile and C. Ceruti (2015), 'Collective capability and collective agency for sustainability: A case study', Ecological Economics, 118, 226-239.

*Penzenstadler, B., H. Femmer and D. Richardson (2013), 'Who is the advocate? Stakeholders for sustainability', in GREENS '13: Proceedings of the 2nd International Workshop on Green and Sustainable Software, San Francisco, CA, 20 May, Hoboken, NJ: IEEE Press, pp. 70-77.

*Pesch, U. (2015), 'Tracing discursive space: Agency and change in sustainability transitions', Technological Forecasting and Social Change, 90, 379-388.

*Pruitt, B., S. Waddell, K. Kaeufer and K. Parrot (2005), 'Dialogic approaches to global challenges: Moving from "dialogue fatigue" to dialogic change processes', Generative Dialogue Project Working Paper, 55.

*Reed, M. S. (2008), 'Stakeholder participation for environmental management: A literature review', Biological Conservation, 141 (10), 2417-2431.

*Rhodes, J., B. Bergstrom, P. Lok and V. Cheng (2014), 'A framework for stakeholder engagement and sustainable development in MNCs', Journal of Global Responsibility, 5 (1), 82-103.

*Senge, P. M., B. B. Lichtenstein, K. Kaeufer, H. Bradbury and J. S. Carroll (2007), 'Collaborating for systemic change', MIT Sloan Management Review, 48 (2), 44-55.

Smith, P. A. (2017), 'Stakeholder engagement framework', Information \& Security, 38, 35-45.

*Smith, R. C. and O. S. Iversen (2018), 'Participatory design for sustainable social change', Design Studies, 59, 9-36.

*Sulkowski, A. J., M. Edwards and R. E. Freeman (2018), 'Shake your stakeholder: Firms leading engagement to cocreate sustainable value', Organization \& Environment, 31 (3), 223-241. 
*Van de Kerkhof, M. (2006), 'A dialogue approach to enhance learning for sustainability: A Dutch experiment with two participatory methods in the field of climate change', Integrated Assessment, 6 (4), 7-34.

*van den Berg, J., M. C. Zijp, W. J. Vermeulen and S. Witjes (2019), 'Identifying change agent types and its implications for corporate sustainability integration based on worldviews and contextual factors', Journal of Cleaner Production, 229, 1125-1138.

*Waddell, S. (2016), 'Societal change systems: A framework to address wicked problems', The Journal of Applied Behavioral Science, 52 (4), 422-449.

*Watson, R., H. N. Wilson and E. K. Macdonald (2020), 'Business-nonprofit engagement in sustainability-oriented innovation: What works for whom and why?', Journal of Business Research, 119, 87-98.

*Watson, R., H. N. Wilson, P. Smart and E. K. Macdonald (2018), 'Harnessing difference: A capability-based framework for stakeholder engagement in environmental innovation', Journal of Product Innovation Management, 35 (2), 254-279.

Webb, R., X. Bai, M. S. Smith, R. Costanza, D. Griggs, M. Moglia, ... and C. Ryan (2018), 'Sustainable urban systems: Co-design and framing for transformation', Ambio, 47 (1), 57-77.

*Westley, F., P. Olsson, C. Folke, T. Homer-Dixon, H. Vredenburg, D. Loorbach, ... and B. Banerjee (2011), 'Tipping toward sustainability: Emerging pathways of transformation', Ambio, 40 (7), 762-780.

World Commission on Environment and Development (1987), Our Common Future, Oxford: Oxford University Press. 


\section{APPENDIX}

\section{Table 14A.1 Summary of the 37 articles included in the analysis}

\begin{tabular}{|c|c|c|c|c|c|c|}
\hline $\begin{array}{l}\text { Authors and } \\
\text { publication date }\end{array}$ & Title & Publication & $\begin{array}{c}\text { Individual } \\
\text { level }\end{array}$ & $\begin{array}{l}\text { Firm } \\
\text { level }\end{array}$ & $\begin{array}{c}\text { Industry } \\
\text { level }\end{array}$ & $\begin{array}{c}\text { Societal } \\
\text { level }\end{array}$ \\
\hline Avelino (2009) & $\begin{array}{l}\text { Empowerment and the } \\
\text { challenge of applying transition } \\
\text { management to ongoing projects }\end{array}$ & Policy Sciences & $\mathrm{x}$ & & & \\
\hline $\begin{array}{l}\text { Avelino and } \\
\text { Wittmayer (2016) }\end{array}$ & $\begin{array}{l}\text { Shifting power relations in } \\
\text { sustainability transitions: } \\
\text { A multi-actor perspective }\end{array}$ & \begin{tabular}{|l|} 
Journal of \\
Environmental Policy \\
\& Planning
\end{tabular} & $\mathrm{x}$ & & & $\mathrm{x}$ \\
\hline Brown et al. (2013) & $\begin{array}{l}\text { Actors working the institutions } \\
\text { in sustainability transitions: The } \\
\text { case of Melbourne's stormwater } \\
\text { management }\end{array}$ & $\begin{array}{l}\text { Global } \\
\text { Environmental } \\
\text { Change }\end{array}$ & $\mathrm{x}$ & & & $\mathrm{x}$ \\
\hline $\begin{array}{l}\text { Bulgacov et al. } \\
(2015)\end{array}$ & $\begin{array}{l}\text { Differences in sustainability } \\
\text { practices and stakeholder } \\
\text { involvement }\end{array}$ & $\begin{array}{l}\text { Social Responsibility } \\
\text { Journal }\end{array}$ & & $\mathrm{x}$ & & \\
\hline Dentoni et al. (2018) & $\begin{array}{l}\text { Harnessing wicked problems } \\
\text { in multi-stakeholder partnerships }\end{array}$ & $\begin{array}{l}\text { Journal of Business } \\
\text { Ethics }\end{array}$ & & & & $\mathrm{x}$ \\
\hline Dentoni et al. (2017) & $\begin{array}{l}\text { Pathways of transformation in } \\
\text { global food and agricultural } \\
\text { systems: Implications from } \\
\text { a large systems change theory } \\
\text { perspective }\end{array}$ & \begin{tabular}{|l} 
Current Opinion \\
in Environmental \\
Sustainability
\end{tabular} & $\mathrm{x}$ & & & $\mathrm{x}$ \\
\hline $\begin{array}{l}\text { Fischer and Newig } \\
(2016)\end{array}$ & $\begin{array}{l}\text { Importance of actors and agency } \\
\text { in sustainability transitions: } \\
\text { A systematic exploration of the } \\
\text { literature }\end{array}$ & Sustainability & $\mathrm{x}$ & & & \\
\hline Foxon et al. (2004) & $\begin{array}{l}\text { Towards a sustainable } \\
\text { innovation policy - institutional } \\
\text { structures, stakeholder } \\
\text { participation and mixes of policy }\end{array}$ & \begin{tabular}{|l|} 
Berlin Conference \\
on the Human \\
Dimensions of Global \\
Environmental \\
Change \\
\end{tabular} & & $\mathrm{x}$ & & $\mathrm{x}$ \\
\hline $\begin{array}{l}\text { Frantzeskaki and } \\
\text { Rok (2018) }\end{array}$ & $\begin{array}{l}\text { Co-producing urban } \\
\text { sustainability transitions } \\
\text { knowledge with community, } \\
\text { policy and science }\end{array}$ & $\begin{array}{l}\text { Environmental } \\
\text { Innovation and } \\
\text { Societal Transitions }\end{array}$ & & & & $\mathrm{x}$ \\
\hline Glasbergen (2010) & $\begin{array}{l}\text { Global action networks: Agents } \\
\text { for collective action }\end{array}$ & $\begin{array}{l}\text { Global } \\
\text { Environmental } \\
\text { Change }\end{array}$ & & & & $\mathrm{x}$ \\
\hline $\begin{array}{l}\text { Goodman et al. } \\
(2017)\end{array}$ & $\begin{array}{l}\text { Our collaborative } \\
\text { future: Activities and } \\
\text { roles of stakeholders in } \\
\text { sustainability-oriented } \\
\text { innovation }\end{array}$ & \begin{tabular}{|l|} 
Business Strategy \\
and the Environment
\end{tabular} & $\mathrm{x}$ & & & \\
\hline
\end{tabular}




\section{Research handbook of sustainability agency}

\begin{tabular}{|c|c|c|c|c|c|c|}
\hline $\begin{array}{l}\text { Authors and } \\
\text { publication date }\end{array}$ & Title & Publication & $\begin{array}{c}\text { Individual } \\
\text { level }\end{array}$ & $\begin{array}{l}\text { Firm } \\
\text { level }\end{array}$ & $\begin{array}{c}\text { Industry } \\
\text { level }\end{array}$ & $\begin{array}{c}\text { Societal } \\
\text { level }\end{array}$ \\
\hline Hörisch et al. (2014) & $\begin{array}{l}\text { Applying stakeholder } \\
\text { theory in sustainability } \\
\text { management: Links, similarities, } \\
\text { dissimilarities, and a conceptual } \\
\text { framework }\end{array}$ & $\begin{array}{l}\text { Organization \& } \\
\text { Environment }\end{array}$ & $\mathrm{x}$ & $\mathrm{x}$ & & \\
\hline $\begin{array}{l}\text { Kivimaa et al. } \\
\text { (2019) }\end{array}$ & $\begin{array}{l}\text { Towards a typology of } \\
\text { intermediaries in sustainability } \\
\text { transitions: A systematic review } \\
\text { and a research agenda } \\
\end{array}$ & Research Policy & & & & $\mathrm{x}$ \\
\hline Köhler et al. (2019) & $\begin{array}{l}\text { An agenda for sustainability } \\
\text { transitions research: State of the } \\
\text { art and future directions }\end{array}$ & \begin{tabular}{|l} 
Environmental \\
Innovation and \\
Societal Transitions \\
\end{tabular} & $\mathrm{x}$ & & $\mathrm{x}$ & $\mathrm{x}$ \\
\hline $\begin{array}{l}\text { Koistinen et al. } \\
(2020)\end{array}$ & $\begin{array}{l}\text { Active sustainability actors: } \\
\text { A life course approach }\end{array}$ & $\begin{array}{l}\text { Sustainable } \\
\text { Development }\end{array}$ & $\mathrm{x}$ & & & \\
\hline Kolk (2014) & $\begin{array}{l}\text { Partnerships as a panacea for } \\
\text { addressing global problems: On } \\
\text { rationale, context, impact and } \\
\text { limitations' }\end{array}$ & \begin{tabular}{|l|} 
Social Partnerships \\
for Responsible \\
Business: A Research \\
Handbook \\
\end{tabular} & & & & $\mathrm{x}$ \\
\hline $\begin{array}{l}\text { Loorbach et al. } \\
\text { (2010) }\end{array}$ & $\begin{array}{l}\text { Business strategies for } \\
\text { transitions towards sustainable } \\
\text { systems }\end{array}$ & $\begin{array}{l}\text { Business Strategy } \\
\text { and the Environment }\end{array}$ & & $\mathrm{x}$ & & \\
\hline $\begin{array}{l}\text { Markard et al. } \\
\text { (2012) }\end{array}$ & $\begin{array}{l}\text { Sustainability transitions: An } \\
\text { emerging field of research and } \\
\text { its prospects }\end{array}$ & Research Policy & & & $\mathrm{x}$ & \\
\hline McKee et al. (2014) & $\begin{array}{l}\text { Shift happens: Co-constructing } \\
\text { transition pathways towards } \\
\text { the regional sustainability of } \\
\text { agriculture in Europe' }\end{array}$ & $\begin{array}{l}\text { Farming Systems } \\
\text { Facing Global } \\
\text { Challenges: } \\
\text { Capacities and } \\
\text { Strategies }\end{array}$ & & & & $\mathrm{x}$ \\
\hline Millar et al. (2012) & $\begin{array}{l}\text { An interaction and networks } \\
\text { approach to developing } \\
\text { sustainable organizations }\end{array}$ & \begin{tabular}{|l|} 
Journal of \\
Organizational \\
Change Management \\
\end{tabular} & & & $\mathrm{x}$ & \\
\hline Mont et al. (2014) & $\begin{array}{l}\text { Sustainable lifestyles 2050: } \\
\text { Stakeholder visions, emerging } \\
\text { practices and future research }\end{array}$ & $\begin{array}{l}\text { Journal of Cleaner } \\
\text { Production }\end{array}$ & $\mathrm{x}$ & $\mathrm{x}$ & & $\mathrm{x}$ \\
\hline Mutoko et al. (2014) & $\begin{array}{l}\text { Fostering technological } \\
\text { transition to sustainable } \\
\text { land management through } \\
\text { stakeholder collaboration in the } \\
\text { western highlands of Kenya }\end{array}$ & Land Use Policy & $\mathrm{x}$ & & $\mathrm{x}$ & \\
\hline $\begin{array}{l}\text { Pattberg and } \\
\text { Widerberg (2016) }\end{array}$ & $\begin{array}{l}\text { Transnational multistakeholder } \\
\text { partnerships for sustainable } \\
\text { development: Conditions for } \\
\text { success }\end{array}$ & Ambio & & & & $\mathrm{x}$ \\
\hline $\begin{array}{l}\text { Penzenstadler et al. } \\
\text { (2013) }\end{array}$ & $\begin{array}{l}\text { Who is the advocate? } \\
\text { Stakeholders for sustainability }\end{array}$ & \begin{tabular}{|l|} 
2nd International \\
Workshop on Green \\
and Sustainable \\
Software (GREENS) \\
\end{tabular} & & & $\mathrm{x}$ & \\
\hline
\end{tabular}




\begin{tabular}{|c|c|c|c|c|c|c|}
\hline $\begin{array}{l}\text { Authors and } \\
\text { publication date }\end{array}$ & Title & Publication & $\begin{array}{c}\text { Individual } \\
\text { level }\end{array}$ & $\begin{array}{l}\text { Firm } \\
\text { level }\end{array}$ & $\begin{array}{c}\text { Industry } \\
\text { level }\end{array}$ & $\begin{array}{c}\text { Societal } \\
\text { level }\end{array}$ \\
\hline Pesch (2015) & $\begin{array}{l}\text { Tracing discursive space: } \\
\text { Agency and change in } \\
\text { sustainability transitions }\end{array}$ & $\begin{array}{l}\text { Technological } \\
\text { Forecasting and } \\
\text { Social Change } \\
\end{array}$ & $\mathrm{x}$ & & & \\
\hline Pruitt et al. (2005) & $\begin{array}{l}\text { Dialogic approaches to global } \\
\text { challenges: Moving from } \\
\text { "dialogue fatigue" to dialogic } \\
\text { change processes }\end{array}$ & $\begin{array}{l}\text { Generative Dialogue } \\
\text { Project }\end{array}$ & & & & $\mathrm{x}$ \\
\hline Reed (2008) & $\begin{array}{l}\text { Stakeholder participation for } \\
\text { environmental management: } \\
\text { A literature review }\end{array}$ & $\begin{array}{l}\text { Biological } \\
\text { Conservation }\end{array}$ & & & & $\mathrm{x}$ \\
\hline Rhodes et al. (2014) & $\begin{array}{l}\text { A framework for stakeholder } \\
\text { engagement and sustainable } \\
\text { development in MNCs }\end{array}$ & $\begin{array}{l}\text { Journal of Global } \\
\text { Responsibility }\end{array}$ & & $\mathrm{x}$ & & $\mathrm{x}$ \\
\hline Senge et al. (2007) & $\begin{array}{l}\text { Collaborating for systemic } \\
\text { change }\end{array}$ & $\begin{array}{l}\text { MIT Sloan } \\
\text { Management Review }\end{array}$ & & & & $\mathrm{x}$ \\
\hline $\begin{array}{l}\text { Smith and Iversen } \\
\text { (2018) }\end{array}$ & $\begin{array}{l}\text { Participatory design for } \\
\text { sustainable social change }\end{array}$ & Design Studies & & & & $\mathrm{x}$ \\
\hline $\begin{array}{l}\text { Sulkowski et al. } \\
\text { (2018) }\end{array}$ & $\begin{array}{l}\text { Shake your stakeholder: Firms } \\
\text { leading engagement to cocreate } \\
\text { sustainable value }\end{array}$ & $\begin{array}{l}\text { Organization \& } \\
\text { Environment }\end{array}$ & & $\mathrm{x}$ & & \\
\hline $\begin{array}{l}\text { Van de Kerkhof } \\
\text { (2006) }\end{array}$ & $\begin{array}{l}\text { A dialogue approach to enhance } \\
\text { learning for sustainability: } \\
\text { A Dutch experiment with two } \\
\text { participatory methods in the } \\
\text { field of climate change }\end{array}$ & $\begin{array}{l}\text { Integrated } \\
\text { Assessment }\end{array}$ & & & & $\mathrm{x}$ \\
\hline $\begin{array}{l}\text { van den Berg et al. } \\
\text { (2019) }\end{array}$ & $\begin{array}{l}\text { Identifying change agent } \\
\text { types and its implications } \\
\text { for corporate sustainability } \\
\text { integration based on worldviews } \\
\text { and contextual factors }\end{array}$ & $\begin{array}{l}\text { Journal of Cleaner } \\
\text { Production }\end{array}$ & & $\mathrm{x}$ & & \\
\hline Waddell (2016) & $\begin{array}{l}\text { Societal change systems: } \\
\text { A framework to address wicked } \\
\text { problems }\end{array}$ & $\begin{array}{l}\text { The Journal of } \\
\text { Applied Behavioral } \\
\text { Science }\end{array}$ & & $\mathrm{x}$ & & \\
\hline Watson et al. (2020) & $\begin{array}{l}\text { Business-nonprofit engagement } \\
\text { in sustainability-oriented } \\
\text { innovation: What works for } \\
\text { whom and why? }\end{array}$ & $\begin{array}{l}\text { Journal of Business } \\
\text { Research }\end{array}$ & & & & $\mathrm{x}$ \\
\hline Watson et al. (2018) & $\begin{array}{l}\text { Harnessing difference: } \\
\text { A capability-based framework } \\
\text { for stakeholder engagement in } \\
\text { environmental innovation }\end{array}$ & $\begin{array}{l}\text { Journal of Product } \\
\text { Innovation } \\
\text { Management }\end{array}$ & & $\mathrm{x}$ & & $\mathrm{x}$ \\
\hline Westley et al. (2011) & $\begin{array}{l}\text { Tipping toward sustainability: } \\
\text { Emerging pathways of } \\
\text { transformation }\end{array}$ & Ambio & $\mathrm{x}$ & & & \\
\hline
\end{tabular}

